\title{
Nanosized $\mathrm{FeO}_{x}$ overlayers on Pt-skin surfaces for low temperature CO oxidation
}

\author{
Hong Xu, Qiang Fu* Xinhe Bao \\ State Key Laboratory of Catalysis, Dalian Institute of Chemical Physics, Chinese Academy of Sciences, Dalian 116023, Liaoning, China
}

\section{A R T I C L E I N F O}

Article history:

Received 6 June 2013

Accepted 24 July 2013

Published 20 November 2013

\section{Keywords:}

CO oxidation

Pt-skin

Fe oxide

Interface catalysis

\begin{abstract}
A B S T R A C T
$\mathrm{Pt}-\mathrm{Cu}$ /carbon black catalysts were prepared by an impregnation-reduction method followed by acid leaching. The structure and composition of $\mathrm{Pt}-\mathrm{Cu}$ nanoparticles treated under different conditions were investigated by inductively coupled plasma atomic emission spectrometry, X-ray diffraction, and X-ray photoelectron spectroscopy. $\mathrm{PtCu}_{3}$ alloy formed upon annealing $\mathrm{Pt}-\mathrm{Cu}$ /carbon black catalysts in $\mathrm{H}_{2}$. Acid leaching produced Pt-Cu nanoparticles consisting of Pt-skeleton surface structure and $\mathrm{PtCu}_{3}$ alloy core. The Pt-skeleton could be transformed to well-defined Pt-skin structure through further annealing the leached Pt-Cu nanoparticles in $\mathrm{H}_{2}$. Decorating the Pt-skin surfaces with $\mathrm{Fe}$ oxide nanopatches resulted in enhanced reactivity in the preferential oxidation of $\mathrm{CO}$ in excess $\mathrm{H}_{2}$. The tri-component $\mathrm{Pt}-\mathrm{Cu}$-Fe catalysts exhibited comparable activity to the bi-component Pt-Fe catalysts but used much less Pt.
\end{abstract}

(C) 2013, Dalian Institute of Chemical Physics, Chinese Academy of Sciences. Published by Elsevier B.V. All rights reserved.

\section{Introduction}

Many important catalytic processes currently make use of Pt-based catalysts. The high cost and low abundance of Pt means that such processes are being challenged to improve catalytic performance, so Pt usage can be reduced. One route to achieving this is the use of Pt-based multi-component catalysts, where Pt is mixed with other transition metals (TMs) such as Fe [1,2], Co [3-5], Ni [6,7], Sn [8], Mo [9], and $\mathrm{Cu}[10,11]$. Pt-based multi-component catalysts have exhibited improved catalytic performance compared with pure Pt catalysts and use much less Pt.

Various configurations have been proposed for Pt-based multi-component catalysts, including core-shell, alloy, and sideby-side structures. Core-shell nanostructures (TM@Pt) with ultrathin Pt shells encapsulating TM or Pt-TM alloy cores have been widely investigated. For example, Pt skin structures are commonly used as active structures for electrocatalytic oxygen reduction reactions [12-15]. TM@Pt $(\mathrm{TM}=\mathrm{Ru}, \mathrm{Rh}, \mathrm{Ir}$, or Pd) core-shell nanoparticles [16-18] also exhibit high activity in the low-temperature preferential oxidation of $\mathrm{CO}$ in excess $\mathrm{H}_{2}$ (CO-PROX). Enhanced PROX reactivity has been attributed to an increased density of CO-free Pt surface sites available for $\mathrm{O}_{2}$ activation, and also a $\mathrm{H}_{2}$-mediated $\mathrm{O}_{2}$ activation mechanism at Pt shell surfaces. Ko et al. [19] reported that PtCo alloy nanoparticles are highly active in low-temperature PROX. Komatsu et al. [20] suggested that the formation of $\mathrm{Pt}_{3} \mathrm{Co}$ or $\mathrm{PtCu}$ intermetallic compounds is responsible for high PROX activity at low temperature.

We recently demonstrated an inverse catalytic system consisting of Pt surfaces decorated with TM (Fe, Co, Ni) oxide nanolayers (TMO-on-Pt), which exhibits high catalytic activity in low-temperature oxidations [21-25]. An interface confinement effect between the TMO and Pt stabilizes coordinatively

\footnotetext{
*Corresponding author. Tel: +86-411-84379253; Fax: +86-411-84694447; E-mail: qfu@dicp.ac.cn

This work was supported by the National Natural Science Foundation of China $(21222305,11079005,20923001)$ and the National Basic Research Program of China (973 Program, 2013CB834603, 2011CBA00503, 2013CB933100). DOI: 10.1016/S1872-2067(12)60673-1 | http://www.sciencedirect.com/science/journal/18722067 | Chin. J. Catal., Vol. 34, No. 11, November 2013
} 
unsaturated (CUS) cations at oxide-Pt boundaries, which are highly active for $\mathrm{O}_{2}$ activation. The supported inverse nanocatalysts were constructed by decorating Pt nanoparticles with TMO nanopatches, and have been used in CO oxidation reactions. To minimize Pt usage, Cu@Pt core-shell nanoparticles were synthesized by a colloid chemistry method [26,27]. FeO nanopatches supported on $\mathrm{Cu@Pt} \mathrm{core-shell} \mathrm{nanoparticles}$ have been reported to exhibit similar CO conversion efficiency to FeO-on-Pt catalysts, but only use $0.9 \% \mathrm{Pt}$ rather than $4 \% \mathrm{Pt}$ in the latter [28]. Ultrathin Pt skin structure can confine active ferrous centers, similar to bulk Pt.

Acid leaching of Pt-based alloy nanostructures can produce Pt-rich surface structures through the preferential removal of less-precious TM atoms from alloy particle surfaces [14,29-34]. Acid leaching is a simple process for obtaining Pt skin surfaces, which can then support highly active TMO nanostructures. Herein, PtCu alloy nanoparticles are leached by acid solutions to produce Pt skin structure, which is used as supports for nanostructured iron oxide. The tri-component catalysts consisting of surface $\mathrm{FeO}_{x}$ nanopatches and surface Pt-rich Pt-Cu nanoparticles exhibit higher PROX activity than pure Pt catalysts. Activity is comparable to that of $\mathrm{FeO}$-on-Pt catalysts, with the tri-component catalyst using much less Pt.

\section{Experimental}

\subsection{Preparation}

$\mathrm{PtCu}$ /carbon black (CB) samples were prepared by co-impregnation using $\mathrm{H}_{2} \mathrm{PtCl}_{6} \cdot 6 \mathrm{H}_{2} \mathrm{O}$ (Shenyang Nonferrous Metal Research Institute, China) and $\mathrm{Cu}\left(\mathrm{NO}_{3}\right)_{2} \cdot 3 \mathrm{H}_{2} \mathrm{O}$ (Tianjin Kemiou Chemical Reagent Co., Ltd., China) precursors. The Pt loading was $1 \%$ (mass fraction), and the $\mathrm{Pt}: \mathrm{Cu}$ molar ratio varied from 1:2 to $1: 12$. Samples were dried overnight at $60{ }^{\circ} \mathrm{C}$ (denoted as-prepared $\mathrm{PtCu} / \mathrm{CB}$ ) and then reduced in pure $\mathrm{H}_{2}$ at $750{ }^{\circ} \mathrm{C}$ for $2 \mathrm{~h}$ (donated $\mathrm{PtCu} / \mathrm{CB} @ 750 \mathrm{H}_{2}$ ). For acid leaching, 25 mg of reduced sample was immersed in $25 \mathrm{~mL}$ of dilute $\mathrm{HNO}_{3}$ at room temperature. After filtering and thoroughly washing with deionized water, leached $\mathrm{PtCu} / \mathrm{CB}$ was obtained. The leached samples were further annealed in $\mathrm{H}_{2}$ at various temperatures for $2 \mathrm{~h}$. Fe oxide was impregnated into the leached $\mathrm{PtCu} / \mathrm{CB}$ samples from $\mathrm{Fe}\left(\mathrm{NO}_{3}\right)_{3}$, to produce $\mathrm{FeO}-$ on- $\mathrm{PtCu} / \mathrm{CB}$.

\subsection{Characterization}

The as-prepared $\mathrm{PtCu} / \mathrm{CB}$ or $\mathrm{PtCu} / \mathrm{CB} @ 750 \mathrm{H}_{2}$ (25 mg) was washed in $25 \mathrm{~mL}$ of $\mathrm{HNO}_{3}$ solution (29 mmol/L). Pt and $\mathrm{Cu}$ concentrations of leached solutions were analyzed by inductively coupled plasma atomic emission spectrometry (ICP-AES, ICPS-8100, Shimadzu, Japan). Leached PtCu/CB was annealed in air at $550{ }^{\circ} \mathrm{C}$ to remove the CB support, and then dissolved in aqua regia. $\mathrm{Pt}$ and $\mathrm{Cu}$ concentrations of leached solutions were measured by ICP. X-ray diffraction (XRD) patterns were collected on a Rigaku D/Max 2500 diffractometer using $\mathrm{Cu} K_{\alpha}(\lambda=$ $0.15406 \mathrm{~nm}$ ) radiation. X-ray photoelectron spectroscopy (XPS) measurements were performed using a Thermo Scientific ESCALAB 250Xi instrument. Spectra were obtained using an $\mathrm{Al} K_{\alpha} \mathrm{X}$-ray source, with the $\mathrm{C} 1 s$ peak at $284.6 \mathrm{eV}$ used as a reference for binding energy. In-situ CO chemisorption was carried out at $40{ }^{\circ} \mathrm{C}$ on a Quantachrome AUTOSORB-1-MS Chemisorb apparatus.

\subsection{Catalytic activity}

CO-PROX was carried out in a purpose-built microreactor using gas chromatography (GC, Agilent GC 6890) to analyze the gas composition. The reaction gas composition was CO: $\mathrm{O}_{2}: \mathrm{H}_{2}=$ 1:0.5:98.5. The gas hourly space velocity (GHSV) was 30000 $\mathrm{mL} /(\mathrm{g} \cdot \mathrm{h})$. Catalysts were reduced in flowing $\mathrm{H}_{2}$ at $250{ }^{\circ} \mathrm{C}$ for 2 $\mathrm{h}$ before reaction. Catalytic performance was investigated from room temperature to $200{ }^{\circ} \mathrm{C}$ at a heating rate of $1{ }^{\circ} \mathrm{C} / \mathrm{min}$.

\section{Results and discussion}

Pt nanoparticles initially form upon reducing Pt-TM catalysts. This is because Pt precursors (e.g. $\mathrm{H}_{2} \mathrm{PtCl}_{6}$ ) can be reduced at low temperature, and reducing TM-containing precursors needs facilitating by $\mathrm{H}$ spillover from the Pt nanoparticles $[35,36]$. Reducing Pt-TM catalysts at elevated temperatures results in an inward diffusion of $3 d-\mathrm{TM}$ atoms toward subsurface regions and the surface segregation of Pt [37-39]. TM atoms at particle surfaces can be dissolved in acid solutions, while those encapsulated by the Pt skin surface structure are unaffected. The $\mathrm{Cu}$ distribution at $\mathrm{PtCu}$ nanoparticle surfaces and in nanoparticle cores can be studied by acid leaching combined with ICP measurements.

Table 1 shows $\mathrm{Cu}$ and $\mathrm{Pt}$ ion concentrations leached from $\mathrm{PtCu} / \mathrm{CB}(1 \% \mathrm{Pt}, 1.2 \% \mathrm{Cu})$ in various acid solutions. Dilute $\mathrm{HNO}_{3}$ was first used to wash as-prepared $\mathrm{PtCu} / \mathrm{CB}$ and $\mathrm{PtCu} / \mathrm{CB} @ 750 \mathrm{H}_{2}$. The former contains unreduced $\mathrm{Pt}$ and $\mathrm{Cu}$ precursor salts, so all $\mathrm{Cu}$ and $\mathrm{Pt}$ ions are expected to dissolve. The measured $\mathrm{Cu}$ and $\mathrm{Pt}$ concentrations in Table 1 are in agreement with the $\mathrm{Pt}$ and $\mathrm{Cu}$ loadings. The amount of $\mathrm{Cu}$ leached from $\mathrm{PtCu} / \mathrm{CB} @ 750 \mathrm{H}_{2}$ is $86 \%$ of that from as-prepared $\mathrm{PtCu} / \mathrm{CB}$. Leached PtCu/CB was further treated in $25 \mathrm{~mL}$ of aqua regia, which can dissolve all $\mathrm{Pt}$ and $\mathrm{Cu}$. The measured $\mathrm{Cu}$ amount is $19 \%$ of that of as-prepared $\mathrm{PtCu} / \mathrm{CB}$, which remains inside nanoparticles after leaching with $\mathrm{HNO}_{3}$. ICP data from leaching with $\mathrm{HNO}_{3}$ and aqua regia are consistent with each other, demonstrating that significant $\mathrm{Cu}$ remains within nanoparticles after $\mathrm{H}_{2}$ reduction and $\mathrm{HNO}_{3}$ leaching. The Pt:Cu molar ratio of leached $\mathrm{PtCu} / \mathrm{CB}$ is 1:0.9.

The measured $\mathrm{Pt}: \mathrm{Cu}$ molar ratio of leached $\mathrm{PtCu} / \mathrm{CB}$ is $1: 1$ for $1 \% \mathrm{Pt}-0.6 \% \mathrm{Cu} / \mathrm{CB}$ subjected to the same reduction and leaching treatment. However, Pt:Cu ratios for 1\% Pt- $2.4 \%$ $\mathrm{Cu} / \mathrm{CB}$ and $1 \% \mathrm{Pt}-3.6 \% \mathrm{Cu} / \mathrm{CB}$ samples are much lower. The amount of $\mathrm{Cu}$ diffusing within nanoparticles does not continu-

\section{Table 1}

ICP-AES measurements of $\mathrm{Cu}$ and Pt leached from $1 \% \mathrm{Pt}-1.2 \% \mathrm{Cu} / \mathrm{CB}$ by $\mathrm{HNO}_{3}$ and aqua regia.

\begin{tabular}{lccc}
\hline Sample & Acid solution & $\mathrm{Cu}\left(10^{-6}\right)$ & $\mathrm{Pt}\left(10^{-6}\right)$ \\
\hline As-prepared $\mathrm{PtCu} / \mathrm{CB}$ & $\mathrm{HNO}_{3}$ & 13.4 & 9.1 \\
PtCu/CB@750H & $\mathrm{HNO}_{3}$ & 11.6 & - \\
Leached PtCu/CB & aqua regia & 2.6 & 9.5 \\
\hline
\end{tabular}


ously increase with increasing $\mathrm{Cu}$ loading. Thus, 1\% Pt-1.2\% $\mathrm{Cu} / \mathrm{CB}$ is used in all subsequent experiments.

XRD measurements were used to investigate structural changes of $\mathrm{PtCu} / \mathrm{SiO}_{2}$ catalysts treated under different conditions (Fig. 1(a)). Diffraction by CB interferes with that by $\mathrm{PtCu}$, so $\mathrm{SiO}_{2}$ support was used in XRD measurements. PtCu alloys have face-centered cubic (fcc) structure, with the (111) reflection shifted to higher $2 \theta$ compared with that of pure $\mathrm{Pt}(2 \theta=$ $39.8^{\circ}$ ). The predominant diffraction peak of reduced $\mathrm{PtCu} / \mathrm{SiO}_{2}$ occurs at $42.5^{\circ}$, arising from the $\mathrm{PtCu}_{3}$ alloy structure. The pattern of the leached sample exhibits a similar diffraction peak position. Thus, only surface $\mathrm{Cu}$ is removed during leaching, and particle cores retain the $\mathrm{PtCu}_{3}$ alloy structure. Leached $\mathrm{PtCu}$ nanoparticles are expected to contain a Pt-skeleton surface $[40,41]$, Pt-rich subsurface region, and $\mathrm{Cu}$-rich $\mathrm{PtCu}_{3}$ alloy core (Scheme 1). After annealing the leached sample in $\mathrm{H}_{2}$ at elevated temperature, the weak diffraction peak of the $\mathrm{PtCu}$ alloy $\left(2 \theta=41^{\circ}\right)$ is observed next to that of the PtCus alloy. Deconvolution of the diffraction peak of the leached sample annealed in $\mathrm{H}_{2}$ at $250{ }^{\circ} \mathrm{C}$ shows two distinct alloy phases of $\mathrm{PtCu}$ and $\mathrm{PtCu}_{3}$. This indicates $\mathrm{Cu}$ rearrangement in leached $\mathrm{PtCu}$ nanoparticles during annealing in $\mathrm{H}_{2}$. As leaching removes $\mathrm{Cu}$ from particle surfaces, a $\mathrm{Cu}$ concentration gradient forms between the particle surface and core. Reduction at elevated temperature is
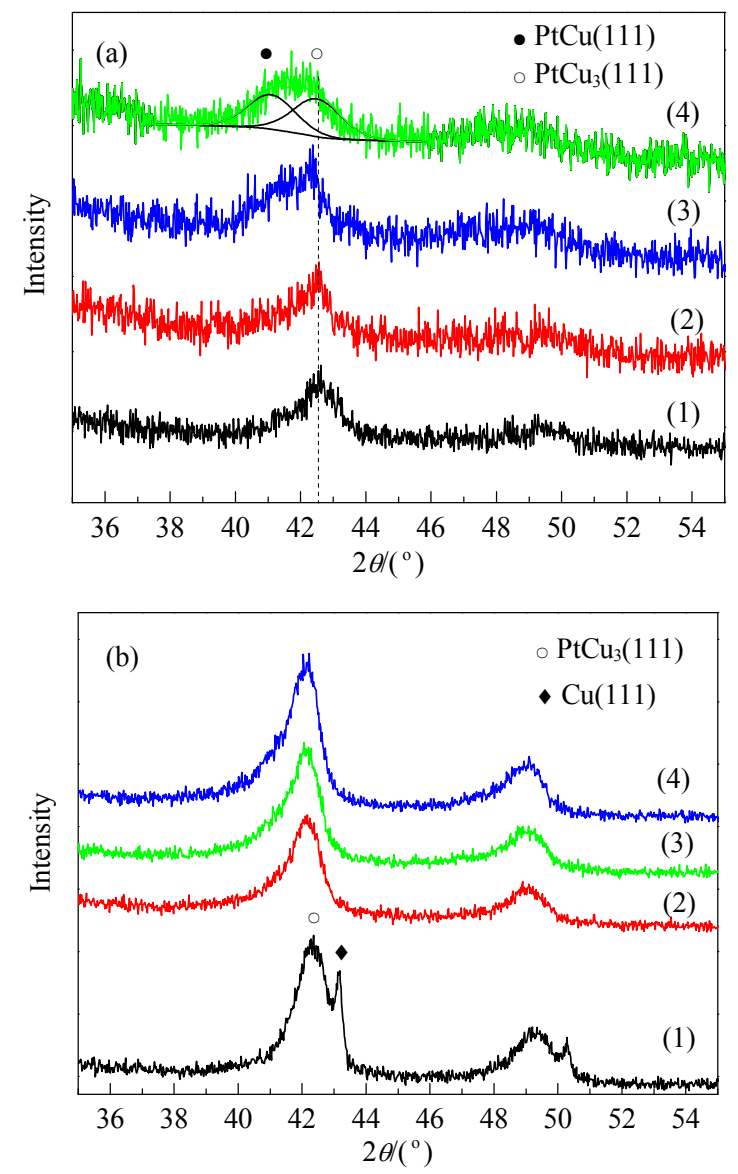

Fig. 1. XRD patterns of $1 \% \mathrm{Pt}-1.2 \% \mathrm{Cu} / \mathrm{SiO}_{2}$ (a) and $4 \% \mathrm{Pt}-4.8 \%$ $\mathrm{Cu} / \mathrm{SiO}_{2}$ (b) subjected to different treatments. (1) $\mathrm{PtCu} / \mathrm{SiO}_{2} @ 750 \mathrm{H}_{2}$; (2) Leached $\mathrm{PtCu} / \mathrm{SiO}_{2}$; (3) Leached $\mathrm{PtCu} / \mathrm{SiO}_{2}$ reduced at $150{ }^{\circ} \mathrm{C}$; (4) Leached $\mathrm{PtCu} / \mathrm{SiO}_{2}$ reduced at $250^{\circ} \mathrm{C}$. thought to result in a slight outward diffusion of $\mathrm{Cu}$ from the $\mathrm{Cu}$-rich core to Pt-rich subsurface, thus forming the $\mathrm{PtCu}$ alloy structure. The signal-to-noise ratio of the $1 \% \mathrm{Pt}-1.2 \% \mathrm{Cu} / \mathrm{SiO}_{2}$ XRD pattern is low because of the low metal loading and small particle size. XRD measurements of $4 \% \mathrm{Pt}-4.8 \% \mathrm{Cu} / \mathrm{SiO}_{2}$ are shown for comparison. A $\mathrm{Cu}(111)$ diffraction peak $\left(2 \theta=43.2^{\circ}\right)$ of $\mathrm{PtCu} / \mathrm{SiO}_{2} @ 750 \mathrm{H}_{2}$ is observed next to that of the $\mathrm{PtCu}_{3}$ alloy phase, and the patterns of all other leached samples exhibit only the PtCus peak (Fig. 1(b)). The selective leaching of $\mathrm{Cu}$ from near surface regions of $\mathrm{Pt}-\mathrm{Cu}$ nanoparticles does not result in a PtCu phase at high Pt loading. This is because of the larger nanoparticle size and $\mathrm{PtCu}_{3}$ phase being predominant within the core.

Samples were further investigated by XPS. Figure 2 shows that all sample spectra contained a Pt $4 f$ peak at $71.3 \mathrm{eV}$ corresponding to $\mathrm{Pt}^{0}$, and its intensity did not show any obvious change. All $\mathrm{Cu} 2 p_{3 / 2}$ binding energy positions were located at $932.4 \mathrm{eV}$, which probably arises from the presence of $\mathrm{Cu}^{0}$. The presence of surface $\mathrm{Cu}_{2} \mathrm{O}$ cannot be excluded because $\mathrm{Cu}$ and $\mathrm{Cu}_{2} \mathrm{O}$ exhibit similar $\mathrm{Cu} 2 p$ binding energy $[42,43] . \mathrm{Cu} 2 p$ peak intensity changes significantly with treatment. The $\mathrm{Pt}: \mathrm{Cu}$ ratio changes from 1:1.6 in $\mathrm{PtCu} / \mathrm{CB} @ 750 \mathrm{H}_{2}$ to 1:0.6 in leached $\mathrm{PtCu} / \mathrm{CB}$ and to $1: 0.8$ in leached $\mathrm{PtCu} / \mathrm{CB}$ reduced at $250{ }^{\circ} \mathrm{C}$. This indicates the selective leaching of surface $\mathrm{Cu}$ and slight outward diffusion of $\mathrm{Cu}$ upon annealing the leached nanoparti-
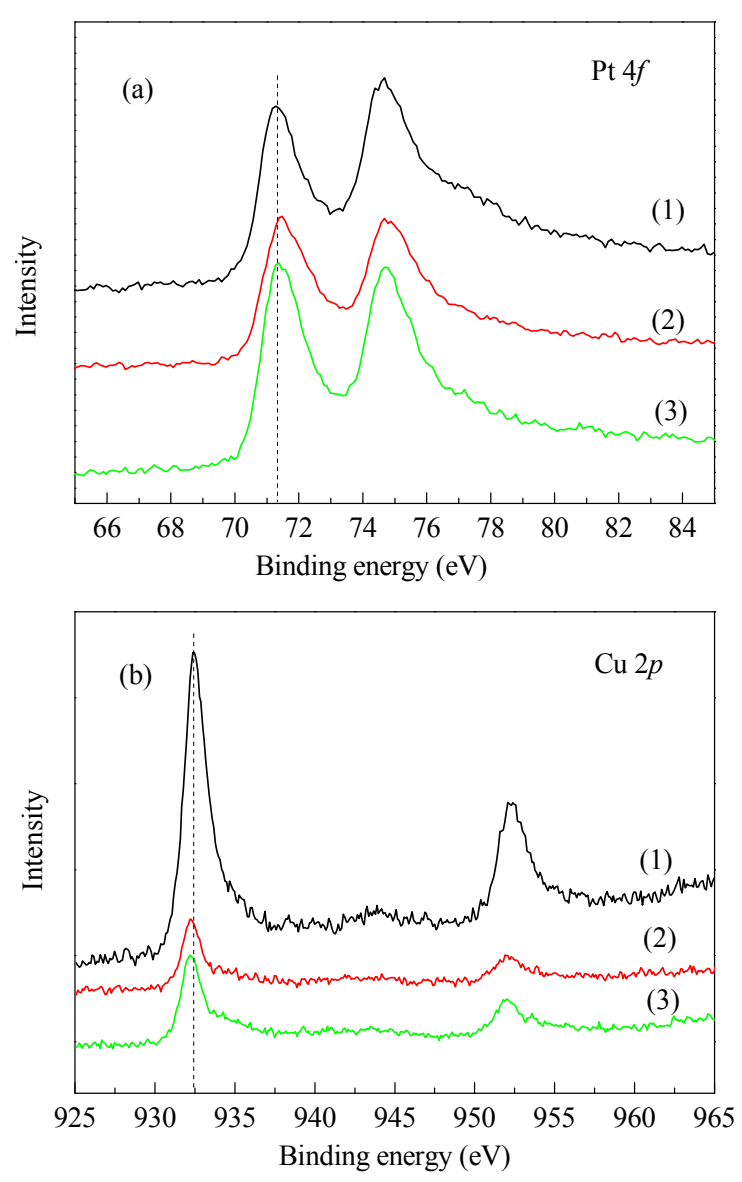

Fig. 2. XPS spectra of the Pt $4 f(\mathrm{a})$ and $\mathrm{Cu} 2 p$ (b) spectral regions of $\mathrm{PtCu} / \mathrm{CB} @ 750 \mathrm{H}_{2}$ (1), leached $\mathrm{PtCu} / \mathrm{CB}$ (2), and leached PtCu/CB reduced at $250^{\circ} \mathrm{C}(3)$. Spectra are normalized to the $\mathrm{C} 1$ s peak intensity. 
cles.

CO chemisorption was carried out to investigate catalyst surface structure. The $\mathrm{CO}$ monolayer uptake of 1\% Pt/CB reduced at $750{ }^{\circ} \mathrm{C}$ is $13.2 \mu \mathrm{mol} / \mathrm{g}$, and that of $\mathrm{PtCu} / \mathrm{CB} @ 750 \mathrm{H}_{2}$ is only $1.7 \mu \mathrm{mol} / \mathrm{g}$. The effect of the $\mathrm{Cu}$ alloy weakens $\mathrm{CO}$ adsorption at the Pt surface $[44,45]$, and surface $\mathrm{Cu}$ also decreases the density of surface Pt sites. The CO monolayer uptake of leached $\mathrm{PtCu} / \mathrm{CB}$ is $7.3 \mu \mathrm{mol} / \mathrm{g}$. In-situ annealing of this sample at 250 ${ }^{\circ} \mathrm{C}$ in $\mathrm{H}_{2}$ decreases the $\mathrm{CO}$ uptake to $4.4 \mu \mathrm{mol} / \mathrm{g}$. The leaching of $\mathrm{PtCu}$ alloy nanoparticles removes surface $\mathrm{Cu}$ sites, thus effectively increasing surface Pt sites available for adsorption. Asleached nanoparticles have a rough surface Pt skeleton $[40,41]$, which is restructured to well-defined facets upon annealing $[29,46]$. This change in surface structure may account for the slight decrease in $\mathrm{CO}$ uptake after annealing leached $\mathrm{PtCu} / \mathrm{CB}$ in $\mathrm{H}_{2}$.

PROX reactions were carried out in the presence of these catalysts. $\mathrm{CO}$ conversion, $\mathrm{O}_{2}$ conversion, and $\mathrm{CO}$ selectivity data are shown in Fig. 3. The Pt/CB catalyst with $1 \%$ Pt loading was first tested as a comparison. The $\mathrm{CO}$ and $\mathrm{O}_{2}$ conversions are $3 \%$ and $4 \%$ at room temperature, respectively, and reach $70 \%$ and $85 \%$ at $200{ }^{\circ} \mathrm{C}$, respectively. $\mathrm{PtCu} / \mathrm{CB} @ 750 \mathrm{H}_{2}$ and leached $\mathrm{PtCu} / \mathrm{CB}$ also exhibit low PROX activity. The $\mathrm{CO}$ selectivity data

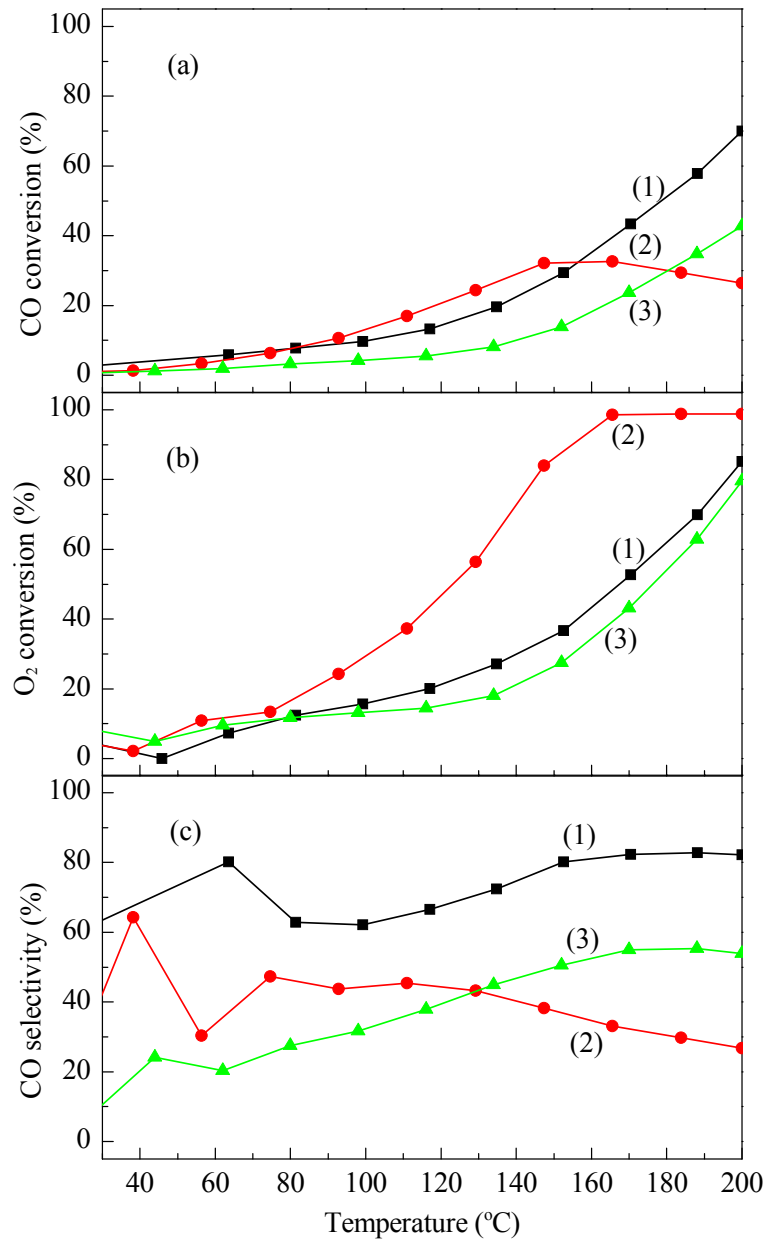

Fig. 3. PROX CO conversion (a), $\mathrm{O}_{2}$ conversion (b), and CO selectivity (c) in the presence of Pt/CB@750H 2 (1), PtCu/CB@750H 2 (2), and leached $\mathrm{PtCu} / \mathrm{CB}(3)$. of these catalysts suggest that a fraction of $\mathrm{O}_{2}$ reacts with $\mathrm{H}_{2}$. In summary, the PtCu alloy surface structure and Pt-skin surface structure exhibit PROX activity similar to that of a pure Pt surface.

Various Fe contents were loaded into leached $\mathrm{PtCu} / \mathrm{CB}$ annealed in $\mathrm{H}_{2}$ at $250{ }^{\circ} \mathrm{C}$. PROX activity is shown in Fig. 4. The catalyst with $0.075 \%$ Fe loading exhibits $\mathrm{CO}$ and $\mathrm{O}_{2}$ conversions of $64 \%$ and $67 \%$ at room temperature, respectively. When Fe loading increases to $0.15 \%$ and $0.3 \%$, catalysts exhibit higher activity, in which CO conversion reaches $90 \%$ at room temperature and $\mathrm{O}_{2}$ conversion is nearly $100 \%$ across the entire temperature range. Although catalytic activity varies with Fe loading, CO selectivity is maintained at $90 \%$ at room temperature. $\mathrm{FeO}_{x}$ addition significantly increases the reaction activity and selectivity, compared with $\mathrm{PtCu} / \mathrm{CB} @ 750 \mathrm{H}_{2}$ and leached $\mathrm{PtCu} / \mathrm{CB}$ in Fig. 3. For comparison, 1\% Pt/CB was annealed in $\mathrm{H}_{2}$ at $750{ }^{\circ} \mathrm{C}$ and loaded with $0.075 \%$ Fe to produce FeO-on-Pt. This catalyst exhibited $40 \%$ CO conversion and $45 \% \mathrm{O}_{2}$ conversion at room temperature. The catalytic performance of $\mathrm{FeO}$ on-Pt with low Pt loading is similar to our previous findings [28].

The above structural investigation suggests that annealing leached samples decreases their surface area and leads to re-

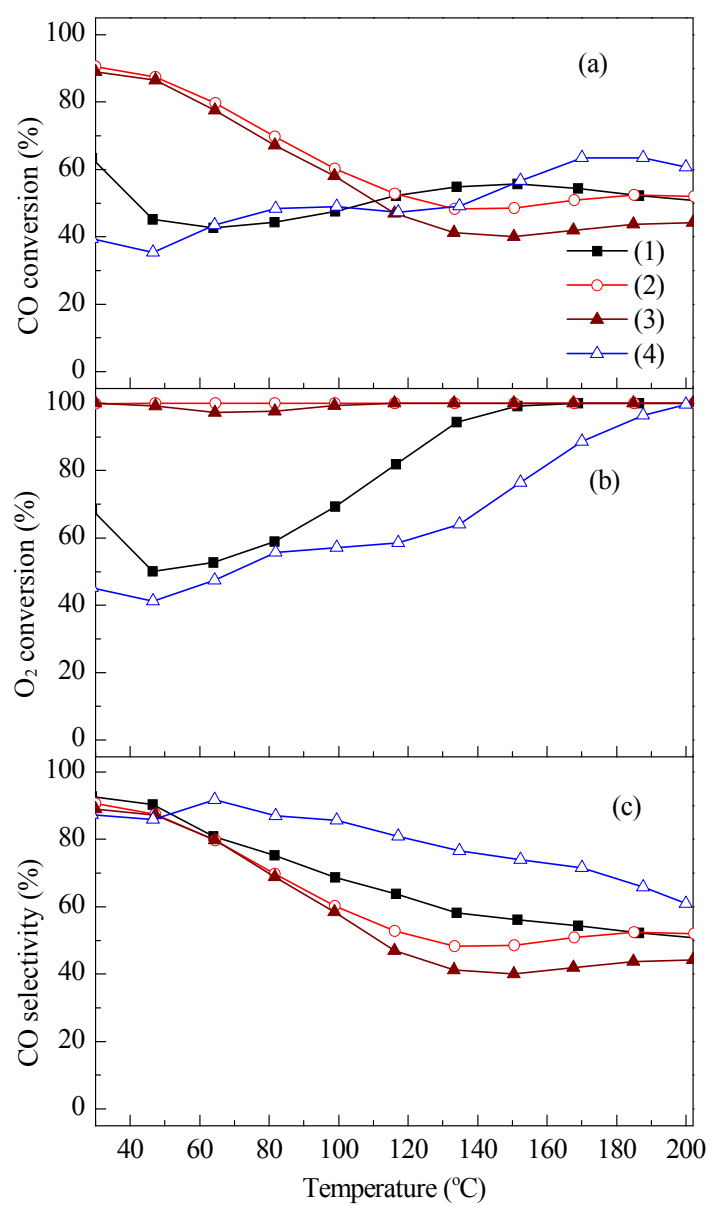

Fig. 4. PROX CO conversion (a), $\mathrm{O}_{2}$ conversion (b), and CO selectivity (c) in the presence of leached $\mathrm{PtCu} / \mathrm{CB}$ annealed at $250{ }^{\circ} \mathrm{C}$ and loaded with $0.075 \% \mathrm{Fe}(1), 0.15 \% \mathrm{Fe}(2)$, and 0.3\% Fe (3), and Pt/CB@750H 2 loaded with $0.075 \% \mathrm{Fe}(4)$. 
construction of their rough surfaces. The effect of annealing temperature on PROX activity of $\mathrm{FeO}-\mathrm{on}-\mathrm{PtCu} / \mathrm{CB}$ was therefore investigated. Figure 5 shows PROX activity of the leached $\mathrm{PtCu} / \mathrm{CB}$ samples, which have been annealed in $\mathrm{H}_{2}$ at various temperatures and then loaded with $0.15 \%$ Fe. For leached $\mathrm{PtCu} / \mathrm{CB}$ not annealed and annealed at $150{ }^{\circ} \mathrm{C}$, the resulting FeO-on-PtCu/CB catalysts exhibit similar activity with $\mathrm{CO}$ and $\mathrm{O}_{2}$ conversions of $\sim 80 \%$ and $\sim 85 \%$ at room temperature, respectively. For leached $\mathrm{PtCu} / \mathrm{CB}$ annealed at $250{ }^{\circ} \mathrm{C}$, the resulting $\mathrm{FeO}-\mathrm{on}-\mathrm{PtCu} / \mathrm{CB}$ catalyst exhibits $\mathrm{CO}$ and $\mathrm{O}_{2}$ conversions of $90 \%$ and $100 \%$ at room temperature, respectively.

From the above characterization, several structural configurations of Pt-Cu nanoparticles are identified and are shown in Scheme 1. Annealing Pt- $\mathrm{Cu}$ in $\mathrm{H}_{2}$ at elevated temperature forms an alloy between $\mathrm{Pt}$ and $\mathrm{Cu}$, probably with additional $\mathrm{Cu}$ nanopatches at particle surfaces. Acid leaching selectively removes $\mathrm{Cu}$ species outside of and at nanoparticle surfaces. Leaching produces Pt-Cu nanoparticles with Pt-skeleton surfaces, which may also influence subsurface regions to a depth of a few monolayers, as suggested previously $[29,47]$. Following leaching, nanoparticles have Pt-skeleton surfaces and $\mathrm{Cu}$-rich alloy cores (Scheme 1). Restructuring of particle surfaces subsequently occurs upon annealing leached nanoparticles in $\mathrm{H}_{2}$, in which

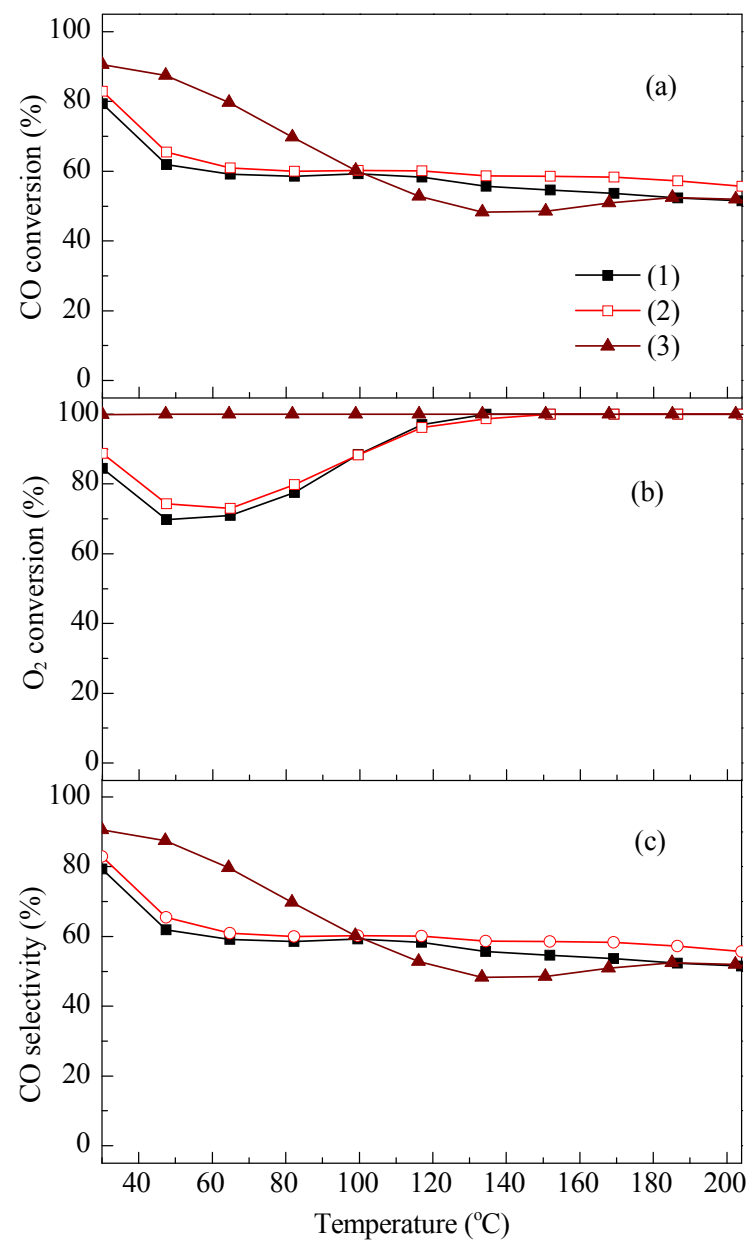

Fig. 5. PROX CO conversion (a), $\mathrm{O}_{2}$ conversion (b), and CO selectivity (c) in the presence of leached $\mathrm{PtCu} / \mathrm{CB}$ annealed at room temperature (1), $150^{\circ} \mathrm{C}(2)$, and $250^{\circ} \mathrm{C} \mathrm{(3)}$, and then loaded with $0.15 \% \mathrm{Fe}$.

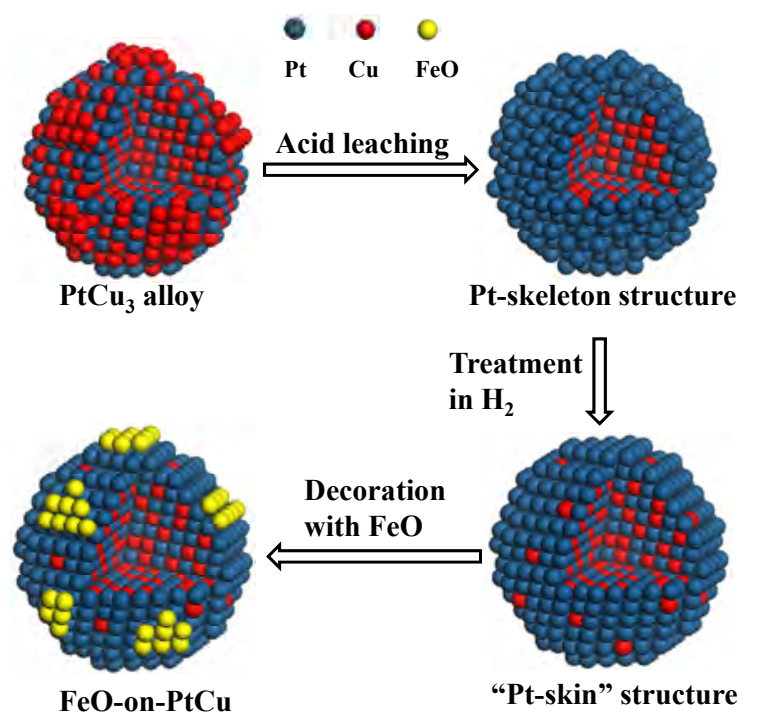

Scheme 1. Schematic showing Pt-Cu nanoparticle structure after various treatments.

the rough Pt-skeleton surface transforms to a well-defined "Pt-skin" structure. A slight outward diffusion of $\mathrm{Cu}$ occurs from the $\mathrm{PtCu}_{3}$ alloy core to Pt-rich near-surface regions.

Leaching and annealing cause a Pt-skin structure formed on a Cu-rich core. This surface structure is not PROX active and exhibits performance similar to that of the pure Pt catalyst (Fig. 3). This differs from the reported high PROX activity of Ru@Pt catalysts $[16,17]$. Pt-skin surfaces decorated with $\mathrm{FeO}_{x}$ nanopatches exhibit higher PROX activity than FeO-Pt catalysts with similar Pt contents. This further confirms the PROX activity of the oxide-on-Pt structure [25]. Leaching and annealing are a simpler method of preparing Pt-skin structure, compared with sequential polyol processes used to prepare Cu@Pt core-shell nanoparticles [28].

\section{Conclusions}

A tri-component catalyst consisting of surface $\mathrm{FeO}_{x}$ nanopatches, Pt-skin surface, and $\mathrm{Cu}$-rich $\mathrm{PtCu}_{3}$ alloy core was prepared. It exhibited high PROX activity and used less Pt than $\mathrm{Pt}-\mathrm{Fe}$ catalysts. The Pt-skin was prepared by alloying $\mathrm{Pt}$ and $\mathrm{Cu}$ via annealing in $\mathrm{H}_{2}$ and subsequent leaching of the $\mathrm{PtCu}$ alloy in acid solution. PtCu nanoparticles with Pt-skins exhibit PROX activity similar to that of pure Pt catalysts. Decorating Pt-skin surfaces with $\mathrm{FeO}_{x}$ nanopatches enhances PROX reactivity. Thus, a highly active tri-component catalyst was easily obtained and used much less Pt than conventional analogs.

\section{References}

[1] Guo S J, Sun S H. J Am Chem Soc, 2012, 134: 2492

[2] Zhou C M, Chen Y T, Guo Z, Wang X, Yang Y H. Chem Commun, 2011, 47: 7473

[3] Chen S, Ferreira P J, Sheng W C, Yabuuchi N, Allard L F, Yang S H. J Am Chem Soc, 2008, 130: 13818

[4] Wang C, Wang G F, van der Vliet D, Chang K C, Markovic N M, 


\section{Graphical Abstract}

Chin. J. Catal., 2013, 34: 2029-2035 doi: 10.1016/S1872-2067(12)60673-1

\section{Nanosized $\mathrm{FeO}_{x}$ overlayers on Pt-skin surfaces for low temperature CO oxidation}

Hong Xu, Qiang Fu*, Xinhe Bao*

Dalian Institute of Chemical Physics, Chinese Academy of Sciences

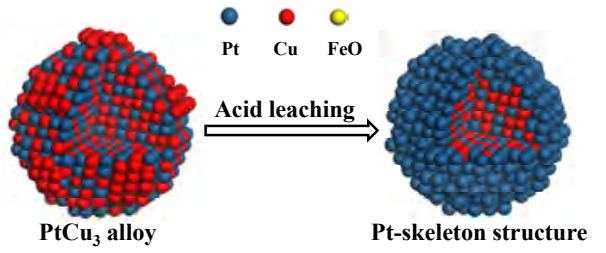

The structural transformation of Pt-Cu catalysts upon reduction-leaching treatment is reported. Pt skin surfaces decorated with surface $\mathrm{FeO}_{x}$ nanostructures exhibit enhanced reactivity in $\mathrm{CO}$ preferential oxidation and use less Pt than Pt-Fe catalysts.
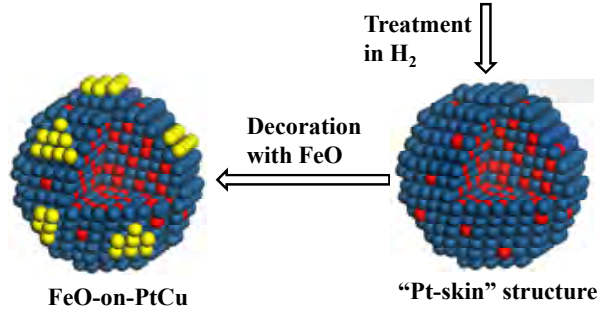

Stamenkovic V R. Phys Chem Chem Phys, 2010, 12: 6933

[5] Wu B H, Huang H Q, Yang J, Zheng N F, Fu G. Angew Chem Int Ed, 2012, 51: 3440

[6] Snyder J, Fujita T, Chen M W, Erlebacher J. Nat Mater, 2010, 9: 904

[7] Jeon T Y, Yoo S J, Cho Y H, Lee K S, Kang S H, Sung Y E. J Phys Chem C, 2009, 113: 19732

[8] Liu Z F, Jackson G S, Eichhorn B W. Angew Chem Int Ed, 2010, 49: 3173

[9] Liu Z F, Hu J E, Wang Q, Gaskell K, Frenkel A I, Jackson G S, Eichhorn B. J Am Chem Soc, 2009, 131: 6924

[10] Gupta G, Slanac D A, Kumar P, Wiggins-Camacho J D, Wang X Q Swinnea S, More K L, Dai S, Stevenson K J, Johnston K P. Chem Mater, 2009, 21: 4515

[11] Oezaslan M, Hasché F, Strasser P. J Electrochem Soc, 2012, 159: B444

[12] Mayrhofer K J J, Juhart V, Hartl K, Hanzlik M, Arenz M. Angew Chem Int $E d, 2009,48: 3529$

[13] Zhou W P, Yang X F, Vukmirovic M B, Koel B E, Jiao J, Peng G W, Mavrikakis M, Adzic R R. J Am Chem Soc, 2009, 131: 12755

[14] Shao M H, Shoemaker K, Peles A, Kaneko K, Protsailo L. J Am Chem Soc, 2010, 132: 9253

[15] Gong K P, Su D, Adzic R R. J Am Chem Soc, 2010, 132: 14364

[16] Alayoglu S, Eichhorn B. J Am Chem Soc, 2008, 130: 17479

[17] Alayoglu S, Nilekar A U, Mavrikakis M, Eichhorn B. Nat Mater, 2008, 7: 333

[18] Nilekar A U, Alayoglu S, Eichhorn B, Mavrikakis M. J Am Chem Soc, 2010, 132: 7418

[19] Ko E Y, Park E D, Lee H C, Lee D, Kim S. Angew Chem Int Ed, 2007, 46: 734

[20] Komatsu T, Tamura A. J Catal, 2008, 258: 306

[21] Fu Q, Li W X, Yao Y X, Liu H Y, Su H Y, Ma D, Gu X K, Chen L M, Wang Z, Zhang H, Wang B, Bao X H. Science, 2010, 328: 1141

[22] Xu H, Fu Q, Yao Y X, Bao X H. Energy Environ Sci, 2012, 5: 6313

[23] Xu H, Fu Q Guo X G, Bao X H. ChemCatChem, 2012, 4: 1645

[24] Mu R T, Fu Q, Xu H, Zhang H, Huang Y Y, Jiang Z, Zhang S, Tan D L, Bao X H.J Am Chem Soc, 2011, 133: 1978

[25] Fu Q Yang F, Bao X H. Acc Chem Res, 2013, 46: 1692

[26] Teng X W, Black D, Watkins N J, Gao Y L, Yang H. Nano Lett, 2003, 3: 261
[27] Teng X W, Yang H.J Am Chem Soc, 2003, 125: 14559

[28] Guo X G, Fu Q, Ning Y X, Wei M M, Li M R, Zhang S, Jiang Z, Bao X H. J Am Chem Soc, 2012, 134: 12350

[29] Strasser P, Koh S, Anniyev T, Greeley J, More K, Yu C F, Liu Z C, Kaya S, Nordlund D, Ogasawara H, Toney M F, Nilsson A. Nat Chem, 2010, 2: 454

[30] Mani P, Srivastava R, Strasser P.J Phys Chem C, 2008, 112: 2770

[31] Koh S, Strasser P. J Am Chem Soc, 2007, 129: 12624

[32] Snyder J, McCue I, Livi K, Erlebacher J. J Am Chem Soc, 2012, 134: 8633

[33] Oezaslan M, Heggen M, Strasser P.J Am Chem Soc, 2012, 134: 514

[34] Wang D L, Yu Y C, Xin H L, Hovden R, Ercius P, Mundy J A, Chen H, Richard J H, Muller D A, DiSalvo F J, Abruña H D. Nano Lett, 2012, 12: 5230

[35] Boudart M. Adv Catal, 1969, 20: 153

[36] Sermon P A, Bond G C.J Chem Soc, Faraday Trans 1, 1976, 72: 730

[37] Ma T, Fu Q, Su H Y, Liu H Y, Cui Y, Wang Z, Mu R T, Li W X, Bao X H. ChemPhysChem, 2009, 10: 1013

[38] Mu R T, Fu Q Liu H Y, Tan D L, Zhai R S, Bao X H. Appl Surf Sci, 2009, 255: 7296

[39] Ma T, Fu Q, Cui Y, Zhang Z, Wang Z, Tan D L, Bao X H. Chin J Catal (马腾, 傅强, 崔义, 张镇, 王珍, 谭大力, 包信和. 催化学报), 2010, 31: 24

[40] Stamenkovic V R, Mun B S, Mayrhofer K J J, Ross P N, Markovic N M. J Am Chem Soc, 2006, 128: 8813

[41] Stamenkovic V R, Mun B S, Arenz M, Mayrhofer K J J, Lucas C A, Wang G F, Ross P N, Markovic N M. Nat Mater, 2007, 6: 241

[42] Poulston S, Parlett P M, Stone P, Bowker M. Surf Interface Anal, 1996, 24: 811

[43] Espinós J P, Morales J, Barranco A, Caballero A, Holgado J P, González-Elipe A R.J Phys Chem B, 2002, 106: 6921

[44] Knudsen J, Nilekar A U, Vang R T, Schnadt J, Kunkes E L, Dumesic J A, Mavrikakis M, Besenbacher F. J Am Chem Soc, 2007, 129: 6485

[45] Yeates R C, Somorjai G A. Surf Sci, 1983, 134: 729

[46] Cui C H, Li H H, Liu X J, Gao M R, Yu S H. ACS Catal, 2012, 2: 916

[47] Wang C, Chi M F, Li D G, Strmcnik D, van der Vliet D, Wang G F, Komanicky V, Chang K C, Paulikas A P, Tripkovic D, Pearson J, More K L, Markovic N M, Stamenkovic V R. J Am Chem Soc, 2011, 133: 14396 


\title{
Pt-表层限域的表面 $\mathrm{FeO}_{x}$ 结构用于低温 $\mathrm{CO}$ 氧化反应
}

\author{
徐红，傅 强，包信和 \\ 中国科学院大连化学物理研究所催化基础国家重点实验室, 辽宁大连 116023
}

\begin{abstract}
摘要: 通过简单的浸渍-还原并随后在酸性溶液中处理制备了Pt-Cu双金属催化剂. 利用电感耦合等离子体发射光谱、X射线衍射 和X射线光电子能谱对不同处理条件下的Pt-Cu纳米粒子的结构和组成进行了表征. 研究发现, Pt-Cu催化剂在高温 $\mathrm{H}_{2}$ 中还原形成 了 $\mathrm{PtCu}_{3}$ 合金结构, 酸洗处理后形成了包含Pt-骨架(Pt-skeleton)的表面结构和 $\mathrm{PtCu}_{3}$ 合金核的纳米粒子. 而Pt-骨架结构又可通过在 $\mathrm{H}_{2}$ 中退火转变为规整的Pt-表层(Pt-skin)结构. Pt-表层表面修饰 $\mathrm{Fe}$ 氧化物后在 $\mathrm{CO}$ 选择氧化反应中表现出较好的催化性能. 通过此 方法制备的三金属Pt-Cu-Fe催化剂可达到与Pt-Fe相近的高活性, 并且催化剂中Pt的用量大大降低.
\end{abstract}

关键词: 一氧化碳氧化; 铂-表层; 铁氧化物; 界面催化

收稿日期: 2013-06-06. 接受日期: 2013-07-24. 出版日期: 2013-11-20.

*通讯联系人. 电话: (0411)84379253; 传真: (0411)84694447; 电子信箱: qfu@dicp.ac.cn

基金来源：国家自然科学基金(21222305，11079005，20923001); 国家重点基础研究发展计划(973计划，2013CB834603, 2011CBA00503, 2013CB933100).

本文的英文电子版由Elsevier出版社在ScienceDirect上出版(http://www.sciencedirect.com/science/journal/18722067). 